\title{
Pengaruh Kualitas Jasa Terhadap Kepuasan Pelanggan Pada Wisata Pemandian Air Panas Ciater Spa Resort
}

\author{
Agus Dedi Subagja ${ }^{1}$ \\ Fakultas Ilmu Administrasi Universitas Subang \\ ads_fileinc@yahoo.co.id \\ Iwan Henri Kusnadi ${ }^{2}$ \\ Fakultas Ilmu Administrasi Universitas Subang \\ iwanhenri01@gmail.com
}

\begin{abstract}
Abstrak
Penelitian ini bertujuan untuk mengetahui pengaruh kualitas jasa terhadap kepuasan pelanggan. Jenis penelitian yang dilakukan adalah explantory dengan pendekatan kuantitatif. Jumlah sampel dalam penelitian ini berjumlah 100 responden yang merupakan pelanggan wisata pemandian air panas Ciater SPA Resort Subang. Teknik yang digunakan dalam pengambilan sampel dalam penelitian ini menggunakan teknik insidental sampling. Analisis data yang digunakan adalah Structural Equation Modeling (SEM) dengan Metode Partial Least Score (PLS). Pengumpulan data dilakukan dengan cara penyebaran kuisioner yang telah diuji validitas dan reliabilitasnya. Berdasarkan hasil penelitian ini menunjukan bahwa Kualitas Jasa berpengaruh signifikan terhadap Kepuasan Pelanggan baik secara simultan dan parsial. Dilihat dari hasil koefisien jalur atau factor loading dari variabel laten kualitas jasa terhadap variabel laten kepuasan pelanggan pada wisata pemandian air panas Ciater SPA Resort sebesar 0.632 dengan nilai t-hitung sebesar 13.123.
\end{abstract}

Kata Kunci : Kualitas Jasa, Kepuasan Pelanggan

\section{Abstract}

The aim off this study is to examine the effect of product quality and service qualitty to customer statisfaction. The type of research is explanatory with quantitative approach. The number of sample in this study amounted to 100 respondents who are customer of hot spring tour Ciater SPA Resort Subang. Sampling technique used in this research is insidental sampling technique. Analysis of the data used is Structural Equation Modeling (SEM) with the method Partial Least Score (PLS). The data collection was done by distributing questionnaries that have been tested for validity and reliability. Based on the results show that Service Quality significantly infuence Costomer Satisfaction both simultaneously and partially. Seen from the results of the path coefficient or factor loading from the service 


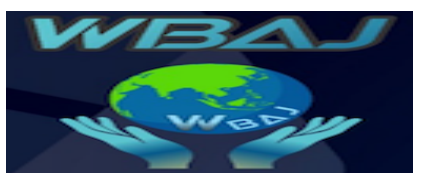

Volume 1 Issue 1, Juni 2019

http://ejournal.unsub.ac.id/index.php/bisnis

quality variable to the costumer statisfaction latent variable on the hot spring Ciater SPA Resort Subang amounting to 0.632 with a t-count value of 13.123.

Keywords : Service Quality, Customer Satisfaction

\section{Pendahuluan}

Dunia bisnis pada saat ini mengalami perkembangan yang semakin pesat. Persaingan untuk menjadi yang terbaikpun merupakan hal mutlak yang harus dicapai agar perusahaan dapat bertahan. Adanya persaingan bisnis ini memunculkan ide-ide baru untuk berinovasi dalam membangun suatu usaha atau menyediakan barang dan jasa agar lebih memiliki keunggulan bahkan ciri khas tersendiri dalam pasar dunia. Kondisi demikian menyebabkan perubahan paradigma dalam dunia pemasaran, sehingga para pelaku usaha khususnya yang mengelola suatu badan usaha menjadi termotivasi dalam mengembangkan kualitas produk maupun jasa yang diberikan agar dapat bersaing dan diterima di pasar dunia. Kualitas produk dan kualitas jasa yang diberikan pada konsumen dapat dijadikan tolak ukur dalam menentukan besarnya kepuasan konsumen terhadap produk dan layanan yang diberikan. Kualitas produk itu sendiri tidak akan memberikan hasil maksimal jika tidak diiringi dengan kualitas jasa yang baik pula, sehingga agar benar-benar bisa bersaing dalam dunia bisnis yang semakin ketat ini. Terdapat beberapa pengertian mengenai pelayanan itu sendiri, seperti yang diungkap oleh Kotler dalam Arief (2007:11) "Jasa adalah sesuatu yang tidak berwujud yang merupakan tindakan atau unjuk kerja yang ditawarkan oleh satu pihak ke pihak lain dan tidak menyebabkan perpindahan kepemilikan apapun". Sedangkan menurut Berry dalam Arief (2007:11) bahwa "Jasa dianggap sebagai tindakan proses dan tampilan yang tidak hanya dihasilkan oleh perusahaan jasa, tetapi merupakan hal yang integral dan ditawarkan juga oleh perusahaan manufaktur".

Kesimpulannya adalah jasa merupakan suatu bentuk tindakan memuaskan kebutuhan atau keinginan yang tidak berwujud, dilakukan melalui proses dan diwujudkan dalam bentuk kinerja yang ditawarkan oleh satu pihak ke pihak lain. Menurut Philip Kotler dan Kevin Lane Keller (2009:139) kepuasan pelanggan itu sendiri merupakan perasaan senang atau kecewa seseorang yang timbul karena membandingkan kinerja yang dipersiapkan produk (atau hasil) terhadap ekspektasi mereka. Jadi kualitas produk atau jasa suatu badan usaha akan dapat mempengaruhi kepuasan pelanggan. Seorang pelanggan yang mendapat pelayanan yang begitu baik akan memberikan tanggapan yang berbeda dengan seorang pelanggan yang mendapatkan pelayanan yang tidak tanggap dan kurang memuaskan. Hal ini sesuai dengan beberapa penelitian sebelumnya dan beberapa teori seperti yang disebutkan oleh Kotler dan Keller (2008:138) “Kualitas adalah fitur dan karakteristik dari suatu produk atau jasa yang membawa kemampuannya untuk menciptakan nilai dan kepuasan pelanggan".

Pemandian air panas Ciater SPA Resort Subang merupakan salah satu sumber air panas alam di daerah kabupaten Subang yang konon menurut sejarah hikayat dapat menyembuhkan berbagai macam penyakit kulit dan penyakit lainnya 


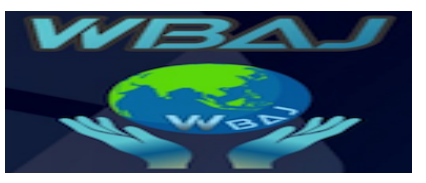

apabila orang berendam dengan air panas yang mengalir langsung dari kawah Gunung Tangkuban Perahu melalui pori-pori tanah ke daerah Ciater. Lokasinya terletak di jalan Raya Ciater Subang. Adanya pencegahan dan penyembuhan berbagai macam penyakit kulit dengan menggunakan sumber air panas alami tersebut konsumen atau pelanggan tidak akan mengalami kesulitan untuk mendapatkan khasiat atau manfaat air panas dengan cara berkunjung ke pemandian air panas Ciater SPA Resort Subang. Selain untuk menyembuhkan penyakit, pemandian air panas Ciater SPA Resort Subang juga menjadi tempat rekreasi sebagai daya tarik pelanggan. Pada Ciater SPA Resort Subang terdapat permasalahan yang dihadapi, dimana pada bulan-bulan tertentu pelanggan yang dicapai di Ciater SPA Resort Subang mengalami penurunan. Ada beberapa kemungkinan yang menyebabkan jumlah pelanggan yang tidak stabil, antara lain karena kualitas pelayanan yang diberikan kurang memuaskan, seperti fasilitas yang kurang memadai, dan lambatnya pelayanan yang diberikan terhadap pelanggan yang menimbulkan complain dan kritikan dari pelanggan yang pernah berkunjung ke Ciater SPA Resort Subang. Tidak dipungkiri bahwa masyarakat memiliki keputusan penilaian terhadap kualitas dan kinerja jasa pada tiap-tiap tempat rekreasi yang pernah dikunjungi. Selain itu, terdapat pula perbedaan kualitas pelayanan di tiap-tiap kolam, misalnya seperti kualitas pelayanan dan fasilitas yang didapat di kolam kunang-kunang pool, kiara pool, dan kamar rendam tentunya akan berbeda.

\section{Kerangka Teori}

\section{Pemasaran}

Masalah-masalah pokok yang diatur dalam manajemen pemasaran ini lebih dititikberatkan tentang cara penjualan barang, jasa, pendistribusian, promosi, produksi sehingga konsumen merasa tertarik untuk mengkonsumsinya. Jadi, mengatur bagaimana supaya barang dan jasa-jasa dapat terjual seoptimal mungkin dan dengan mendapat laba yang wajar. Agar pengertian pemasaran lebih jelas, penulis akan menjelaskan beberapa definisi pemasaran menurut para ahli. Menurut Brech dalam Fandy Tjiptono (2014:2) Pemasaran adalah proses menentukan permintaan konsumen atas sebuah produk atau jasa, memotivasi penjualan produk/jasa tersebut dan mendistribusikannya pada konsumen akhir dengan memperoleh laba.

Menurut Dibb, Simkin, Pride \& Ferrel dalam Fandy Tjiptono (2014:2) Pemasaran didefinisikan sebagai aktivitas individual dan organisasional yang memfasilitasi dan memperlancar hubungan pertukaran yang saling memuaskan dalam lingkungan yang dinamis melalui pengembangan, distribusi, promosi, dan penetapan harga, barang, jasa dan gagasan. Menurut Gronroos dalam Fandy Tjiptono (2014:3) Pemasaran adalah mengembangkan, mempertahankan, dan meningkatkan relasi dengan para pelanggan dan mitra lainnya dengan mendapatkan laba sedemikian rupa sehingga tujuan masing-masing pihak dapat tercapai.

Menurut Kotler dalam Fandy Tjiptono (2014:3) Pemasaran adalah proses sosial dan manajerial dimana individu dan kelompok mendapatkan apa yang 


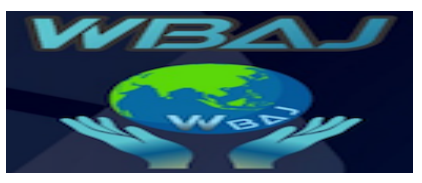

mereka butuhkan dan inginkan melalui penciptaan dan pertukaran produk dan nilai satu sama lain. Berdasarkan pengertian para ahli tersebut, dapat disimpulkan bahwa pemasaran merupakan aktivitas, serangkaian institusi, dan proses menciptakan, mengkomunikasikan, menyampaikan dan mempertukarkan tawaran yang bernilai bagi pelanggan, klien, mitra, dan masyarakat luas.

\section{Kualitas Jasa}

Kualitas jasa jauh lebih sukar didefinisikan, dijabarkan, dan diukur bila dibandingkan dengan kualitas barang. Jasa bersifat intangible dan lebih merupakan proses yang dialami pelanggan secara subyektif, di mana aktivitas produksi dan konsumsi berlangsung pada saat bersamaan. Menurut Wyckof (dalam Fandy Tjiptono $2014: 268$ ), kualitas jasa merupakan tingkat keunggulan (excellence) yang diharapkan dan pengendalian atas keunggulan tersebut untuk memenuhi keinginan pelanggan. Zeithaml (dalam Fandy Tjiptono 2014 : 266) merangkum implikasi kualitas jasa terhadap laba dalam sebuah model konseptual. Dalam bentuk model tersebut, kualitas jasa berkontribusi pada laba melalui dua jalur utama, yaitu pemasaran defensif (defensive marketing) dan pemasaran ofensif (offensive marketing). Pemasaran ofensif berorientasi pada upaya mendapatkan pelanggan baru, sedangkan pemasran defensif berkaitan erat dengan kompetensi organisasi dalam mempertahankan pelanggan. Selain itu, kualitas jasa juga meningkatkan kemampuan organisasi untuk mempertahankan pelanggan yang selanjutnya mempengaruhi profitabilitas melalui faktor efesiensi biaya, peningkatan penjualan, premium harga, dan komunikasi gethok tular positif (Heskett, Sasser \& Schlesinger dalam Fandy Tjiptono $2014: 266$ ) Berdasarkan pandangan tersebut diatas tampak bahwa kualitas jasa merupakan suatu tindakan atau aktivitas yang ditawarkan pada pihak lain dan tidak berwujud tetapi bisa dinikmati manfaatnya dan sebagai usaha pemenuhan dari keinginan pelanggan serta ketetapan penyampaian jasa dalam rangka memenuhi harapan pelanggan. Produktivitas biasanya selalu dikaitkan dengan kualitas dan prifitabilitas. Meskipun demikian, ketiga konsep ini memiliki penekanan yang berbeda-beda (Edvardsson dalam Fandy Tjiptono \& Gregorius Chandra 2011:171).

1) Produktivitas menekankan pemanfaatan (utilisasi) sumber daya, yang seringkali diikuti dengan penekanan biaya dan rasionalisasi modal. Fokus utamanya terletak pada produksi/operasi.

2) Kualitas lebih menekankan aspek kepuasan pelanggan dan pendapatan. Fokus utamanya adalah customer utility.

3) Profitabilitas merupakan hasil dari hubungan antara penghasilan (income), biaya, dan modal yang digunakan.

\section{Prinsip-prinsip Kualitas Jasa}

Dalam rangka menciptakan gaya manajemen dan lingkungan yang kondusif bagi organisasi jasa untuk menyempurnakan kualitas, organisasi bersangkutan harus mampu mengimplementasikan enam prinsip utama yang berlaku baik bagi perusahaan manufaktur maupun organisasi jasa. Menurut Wolkins dalam Fandy Tjiptono \& Gregorius Chandrra (2011:203) enam prinsip tersebut, yaitu :

1) Kepemimpinan; Manajemen puncak harus memimpin dan mengarahkan organisasinya dalam upaya peningkatan kualitas. Tanpa adanya kepemimpinan 
dari manajemen puncak, usaha peningkatan kualitas hanya akan berdampak kecil.

2) Pendidikan; Semua karyawan, mulai dari manajer puncak sampai karyawan oprasional wajib mendapatkan pendidikan mengenai kualitas. Aspek-aspek yang perlu mendapatkan penekanan dalam pendidikan tersebut antara lain konsep kualitas sebagai strategi bisnis, alat dan teknik implementasi strategi kualitas, dan peranan eksklusif dalam implementasi strategi kualitas.

3) Perencanaan Strategik; Proses perencanaan strategik harus mencakup pengukuran dan tujuan kualitas yang dipergunakan dalam mengarahkan untuk mencapai visi dan misinya.

4) Review; Proses review merupakan satu-satunya alat yang paling efektif bagi manajemen untuk mengubah perilaku organisasional. Proses ini menggambarkan mekanisme yang menjamin adanya perhatian terus-menerus terhadap upaya mewujudkan sasaran-sasaran kualitas.

5) Komunikasi; Implementasi strategi kualitas dalam organisasi dipengaruhi oleh proses komunikasi organisasi, baik dengan karyawan, pelanggan, maupun stakeholder lainnya (seperti pemasok, pemegang saham, pemerintah, masyarakat sekitar, dan lain-lain).

6) Total Human Reward; Reward dan recognition merupakan aspek krusial dalam implementasi strategi kualitas jasa. Setiap karyawan berprestasi perlu diberi imbalan dan prestasinya harus diakui.

\section{Faktor penyebab buruknya kualitas jasa}

Menurut Fandy Tjiptono \& Gregorius Chandra (2011:255) setiap perusahaan harus benar-benar memahami jumlah faktor potensial yang bisa menyebabkan buruknya kualitas jasa, diantaranya :

1) Produksi dan konsumsi yang terjadi secara simultan;

Salah satu karakteristik unik jasa adalah inseparability, artinya jasa produksi dan konsumsi pada saat bersamaan. Hal ini kerapkali membutuhkan kehadiran dan partisipasi pelanggan dalam proses penyampaian jasa.

2) Intensitas tenaga kerja yang tinggi;

Keterlibatan karyawan secara intensif dalam penyampaian jasa dapat pula menimbulkan masalah kualitas, yaitu berupa tingginya variabilitas jasa yang dihasilkan.

3) Dukungan terhadap pelanggan internal kurang memadai; $\backslash$

Karyawan front-line merupakan ujung tombak sistem penyampaian jasa. Agar mereka dapat memberikan jasa secara efektif, mereka membutuhkan dukungan dari fungsi-fungsi utama manajemen (operasi, pemasaran, keuangan, dan SDM).

4) Gap komunikasi;

Tidak dapat dipungkiri lagi bahwa komunikasi merupakan faktor esensial dalam menjalin kontak dan relasi dengan pelanggan.

5) Memperlakukan semua pelanggan dengan cara yang sama;

Pelanggan merupakan individu unik dengan prefensi, perasaan, dan emosi maisng-masing. Dalam hal ini interaksi dengan penyedia jasa, tidak semua pelanggan bersedia menerima jasa yang seragam (standardized service).

6) Perluasan atau pengembangan jasa secara berlebihan; 
Di satu sisi, mengintriduksi jasa baru atau menyempurnakan jasa lama dapat meningkatkan peluang pertumbuhan bisnis dan menghindari terjadinya layanan yang buruk. Di sisi lain, bila terlampau banyak jasa baru dan tambahan terhadap jasa yang sudah ada, hasil yang didapatkan belum tentu optimal, bahkan tertutup kemungkinan timbul masalah-masalah seputar standar kualitas jasa.

7) Visi bisnis jangka pendek;

Visi jangka pendek (misalnya, orientasi pada pencapaian target penjualan dan laba tahunan, pengamatan biaya sebesar-besarnya, peningkatan produktivitas tahunan, dan lain-lain) bisa merusak kualitas jasa yang sedang dibentuk untuk jangka panjang.

\section{Dimensi Kualitas Jasa}

Adapun dimensi kualitas jasa yang akan digunakan dalam penelitian ini adalah dimensi menurut Parasuraman dalam Fandy Tjiptono (2014 : 282) yaitu :

1) Reliabilitas (reliability), yakni kemampuan memberikan layanan yang dijanjikan dengan segera, akurat, dan memuaskan

2) Daya tanggap (responsiveness), yaitu keinginan para staff untuk membantu para pelanggan dan memberikan layanan daya tanggap

3) Jaminan (assurance), mencakup pengetahuan, kompetensi, kesopanan, dan sifat dapat dipercaya yang dimiliki para staff; bebas dari bahaya, risiko atau keraguraguan.

4) Empati (empathy), meliputi kemudahan dalam menjalin relasi, komunikasi yang baik, perhatian pribadi, dan pemahaman atas kebutuhan individual pelanggan.

5) Bukti fisik (tangibles), meliputi fasilitas fisik, perlengkapan, pegawai, dan sarana komunikasi.

\section{Kepuasan Pelanggan}

Kata 'kepuasan atau satisfaction' berasal dari bahasa latin "satis" (artinya cukup baik, memadai) dan "facio" (melakukan atau membuat). Secara sederhana kepuasan dapat diartikan sebagai 'upaya pemenuhan sesuatu' atau 'membuat sesuatu memadai'. Ini bisa dilihat dari beragam definisi yang dikemukakan para ahli. Menurut Philip Kotler dan Kevin Lane Keller (2009:139) kepuasan pelanggan adalah perasaan senang atau kecewa seseorang yang timbul karena membandingkan kinerja yang dipersiapkan produk (atau hasil) terhadap ekspektasi mereka. Howard \& Sheth dalam Fandy Tjiptono (2014:353) mengungkapkan bahwa kepuasan pelanggan adalah situasi kognitif pembeli berkenaan dengan kesepadanan atau ketidaksepadanan antara hasil yang didapatkan dibandingkan dengan pengorbanan yang dilakukan. Westbrook \& Reilly dalam Fandy Tjiptono (2014:353) berpendapat bahwa kepuasan pelanggan adalah respon emosional terhadap pengalaman-pengalaman berkaitan dengan produk atau jasa tertentu yang dibeli, gerai ritel, atau bahkan pola perilaku (seperti perilaku berbelanja dan perilaku pembeli), serta pasar secara keseluruhan. Dari beberapa definisi diatas, dapat disimpulkan bahwa kepuasan pelanggan merupakan penilaian pelanggan terhadap produk atau jasa yang telah memberikan kepuasan seperti yang diharapkan, karena dengan adanya kepuasan pelanggan maka kelangsungan usahapun akan terjaga. 
Menurut Fandy Tjiptono (2014:356) kepuasan pelanggan melalui perencanaan, pengimplementasian, dan pengendalian program khusus berpotensi memberikan beberapa manfaat pokok, diantaranya :

1) Reaksi terhadap produsen berbiaya rendah;

Dalam berbagai kasus, hal ini menyebabkan pemotongan harga menjadi senjata strategik untuk meraih pangsa pasar. Fokus pada kepuasan pelanggan merupakan upaya mempertahankan pelanggan dalam rangka menghadapi para produsen berbiaya rendah. Banyak perusahaan yang mendapati bahwa cukup banyak banyak pelanggan yang sebenarnya bersedia membayar harga yang lebih mahal untuk pelayanan dan kualitas yang lebih baik.

2) Manfaat ekonomik retensi pelanggan versus perpetual prospecting;

Berbagai studi menunjukan bahwa mempertahankan dan memuaskan pelanggan saat ini jauh lebih murah dibandingkan upaya terus-menerus menarik atau memprospek pelanggan baru. Riset yang dilakukan Wells dalam Fandy Tjiptono (2014:357) misalnya, menunjukkan bahwa biaya mempertahankan pelanggan lebih murah 4 sampai 6 kali lipat dibandingkan biaya mencari pelanggan baru.

3) Nilai kumulatif dari relasi berkelanjutan;

Berdasarkan konsep "customer lifetime value" upaya mempertahankan loyalitas pelanggan terhadap produk dan jasa perusahaan selama periode waktu yang lama bisa menghasilkan anuitas yang jauh lebih besar daripada pembelian individual.

4) Daya parsuasif gethok tular (word of mouth);

Dalam banyak industri (terutama sektor jasa), pendapat/opini positif dari teman dan keluarga jauh lebih persuasif dan kredibel ketimbang iklan. Oleh sebab itu, banyak perusahaan yang tidak hanya meneliti kepuasan total, namun juga menelaah sejauh mana pelanggan bersedia merekomendasikan produk perusahaan kepada orang lain. Sebaliknya, gethok tular negatif bisa merusak reputasi dan citra perusahaan. Pelanggan yang tidak puas bisa mempengaruhi sikap dan penilaian negatif rekan atau keluarganya terhadap barang dan jasa perusahaan. Gethok tular negatif biasanya tersebar jauh lebih cepat dibandingkan gethok tular positif.

5) Reduksi sensitivitas harga;

Pelanggan yang puas dan loyal terhadap sebuah perusahaan cenderung lebih jarang menawar harga untuk setiap pembelian individualnya. Ini dikarenakan faktor kepercayaan (trust) telah terbentuk. Pelanggan yakin bahwa perusahaan langganannya tidak bakal bersikap oportunistik dan memanfaatkan mereka untuk kepentingan sesaat. Dalam banyak kasus, kepuasan pelanggan mengalihkan fokus pada harga ke pelayanan dan kualitas.

6) Kepuasan pelanggan sebagai indikator kesuksesan bisnis di masa depan;

Pada hakikatnya kepuasan pelanggan merupakan strategi jangka panjang, karena dibutuhkan waktu cukup lama sebelum bisa membangun dan mendapatkan reputasi atas layanan prima, dan kerapkali juga dituntut investasi besar pada serangkaian aktivitas yang ditujukan untuk membahagiakan pelanggan saat ini dan masa depan.

Menurut Fandy Tjiptono (2014:358) pada umunya kepuasan pelanggan meliputi kombinasi dari tujuh elemen utama, yaitu : 


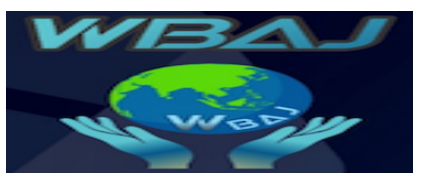

1) Barang dan jasa berkualitas

Perusahaan yang ingin menerapkan program kepuasan pelanggan harus memiliki produk berkualitas baik dan layanan yang prima. Paling tidak standarnya harus menyamai para pesaing utama dalam industri.

2) Relationship marketing

Kunci pokok dalam setiap program promosi loyalitas adalah upaya menjalin relasi jangka panjang dengan para pelanggan. Asumsinya adalah bahwa relasi yang kokoh dan saling menguntungkan antara penyedia jasa dan pelanggan dapat membangun bisnis ulangan (repeat business) dan menciptakan loyalitas pelanggan.

3) Program promosi loyalitas

Program promosi loyalitas banyak diterapkan untuk menjalin relasi antara perusahaan dan pelanggan. Biasanya program ini memberikan semacam penghargaan khusus (seperti bonus, diskon, voucher, dan hadiah yang dikaitkan dengan frekuensi pembelian atau pemakaian produk/jasa perusahaan) kepada pelanggan kelas kakap atau pelanggan rutin agar tetap loyal pada produk dari perusahaan bersangkutan.

4) Fokus pada pelanggan terbaik (best customer)

Sekalipun program promosi loyalitas beraneka ragam bentuknya, namun semuanya memiliki kesamaan pokok dalam hal fokus pada pelanggan yang paling berharga. Program-program semacam itu berfokus pada 20 persen dari pelanggan yang secara rutin mengkonsumsi 80 persen dari penjualan (sesuai denga Prinsip Pareto).

5) Sistem penanganan komplain secara efektif

Penanganan komplain terkait erat dengan kualitas produk. Perusahaan harus terlebih dahulu memastikan bahwa barang dan jasa yang dihasilkan benarbenar berfungsi sebagaimana mestinya sejak awal. Baru setelah itu, jika ada masalah, perusahaan segera berusaha memperbaikinya lewat sistem penanganan komplain.

6) Unconditional guarantees

Unconditional guarantees dibutuhkan untuk mendukung keberhasilan program kepuasan pelanggan. Garansi merupakan janji eksplisit yang disampaikan kepada para pelanggan mengenai tingkat kinerja yang dapat diharapkan bakal mereka terima.

7) Program pay-for-performance

Program kepuasan pelanggan tidak bisa terlaksana tanpa adanya dukungan sumber daya manusia organisasi. Sebagai ujung tombak perusahaan yang berinteraksi langsung dengan para pelanggan dan berkewajiban memuaskan mereka, karyawan juga harus dipuaskan kebutuhannya.

Menurut Kotler \& Keller dalam Fandy Tjiptono (2014:369) ada beberapa metode yang dipergunakan setiap perusahaan untuk mengukur dan memantau kepuasan pelanggannya, antara lain :

1) Sistem Keluhan dan Saran

Setiap organisasi jasa yang berorientasi pada pelanggan wajib memberikan kesempatan seluas-luasnya bagi para pelanggannya untuk menyampaikan saran, kritik, pendapat, dan keluhan mereka.

2) Ghost/Mystery Shopping 
Salah satu metode untuk memperoleh gambaran mengenai kepuasan pelanggan adalah dengan mempekerjakan beberapa orang ghost shoppers untuk berperan sebagai pelanggan potensial jasa perusahaan dan pesaing.

3) Lost Customer Analysis

Perusahaan seyogyanya menghubungi para pelanggan yang telah berhenti membeli atau yang telah beralih pemasok, agar dapat memahami mengapa hal itu terjadi dan supaya dapat mengambil kebijakan perbaikan/penyempurnaan selanjutnya.

4) Survei Kepuasan Pelanggan

Umumnya sebagian besar penelitian mengenai kepuasan pelanggan menggunakan metode survei, baik via pos, telepon, e-mail, maupun wawancara langsung (McNeal \& Lamb, dalam Peterson \& Wilson).

Adapun dimensi kepuasan pelanggan yang akan digunakan dalam penelitian ini adalah dimensi menurut Fandy Tjiptono (2014 : 368) yaitu : Meminta pelanggan menilai produk dan/jasa perusahaan berdasarkan item-item spesifik, seperti kecepatan layanan, fasilitas layanan, atau keramahan staff layanan pelanggan; dan Meminta pelanggan menilai produk dan/jasa pesaing berdasarkan item-item spesifik yang sama, seperti kecepatan layanan, fasilitas layanan atau keramahan staff layanan pelanggan.

\section{Metode Penelitian}

Dalam penelitian ini, penulis akan menggunakan metode penelitian kuantitatif dengan pendekatan Deskriptif dan Eksplansi Survei (Explantory Survey). Metode penelitian kuantitatif dapat diartikan sebagai metode penelitian yang berlandaskan pada filsafat positivisme, digunakan untuk meneliti pada populasi atau sampel tertentu, teknik pengambilan sampel pada umumnya dilakukan secara random, pengumpulan data menggunakan instrumen penelitian, analisis data bersifat kuantitatif/statistik dengan tujuan untuk menguji hipotesis yang telah ditetapkan (Sugiyono, 2014:13).

Filsafat positivisme memandang realitas/gejala/fenomena itu dapat diklasifikasikan, relatif tetap, konkrit, teramati, terukur dan hubungan gejala bersifat sebab akibat. Penelitian pada umunya dilakukan pada populasi atau sampel tertentu yang representatif. Proses penelitian bersifat deduktif, dimana untuk menjawab rumusan masalah digunakan konsep atau teori sehingga dapat dirumuskan hipotesis. Hipotesis tersebut selanjutnya diuji melalui pengumpulan data lapangan. Untuk mengumpulkan data digunakan instrumen penelitian. Data yang telah terkumpul selanjutnya di analisis secara kuantitatif dengan menggunakan statistik deskriptif atau inferensial sehingga dapat disimpulkan hipotesis yang dirumuskan terbukti atau tidak. Penelitian kuantitatif pada umunya dilakukan pada sampel yang diambil secara random, sehingga kesimpulan hasil penelitian dapat digeneralisasikan pada populasi di mana sampel tersebut diambil.

\section{Hasil dan Pembahasan}

\section{Sejarah Singkat Perusahaan}

PT. SARI ATER RAYA adalah sebuah nama badan hukum berbentuk Perseroan ( PT ) yang didirikan oleh Ny. Erwina Soewarma dan Nn. Yularni Avianti 
dengan akta notaris Koswara pada tanggal 27 Februari 1989. Latar belakang didirikannya Perusahaan ini dikarenakan adanya keinginan untuk mengetahui lebih banyak lagi khasiat dan manfaat air panas dari sumber air panas alam yang konon menurut sejarah hikayat dapat menyembuhkan berbagai macam penyakit kulit dan penyakit lainnya apabila orang berendam dengan air panas yang mengalir langsung dari kawah Gunung Tangkuban Perahu melalui pori-pori tanah ke daerah Ciater. Pada saat Bapak H. Soewarma ( President Komisaris ) dan Ibu Erwina Soewarma ( President Director ) berlibur ke Yugoslavia ternyata di Kota Kanjiza terdapat taman rekreasi yang mempunyai sumber air panas alam yang sama dengan yang di Ciater. Di taman rekreasi tersebut air panasnya selain dimanfaatkan sebagai daya tarik juga dipakai untuk mengobatai penyakit. dari hal tersebut Bapak H. Soewarma merasa tertarik, kemudian mendatangi tenaga ahli di pusat rehabilitasi disana. Dalam pertemuan tersebut diadakanlah pembicaraan khusus mengenai air panas alam dan dijajagi kemungkinan apakah sumber air panas yang di Ciater memiliki kandungan yang serupa dengan air panas di taman rekreasi Kanjiza, sehingga air panas alam tersebut dapat bermanfaat lebih baik lagi. Akhirnya diundanglah tenaga ahli dari Kota Kanjiza untuk mereliti lebih lanjut kandungan air panas di Desa Ciater setelah dilakukan penelitian berulang-ulang baik kadar yang terkandung di dalam air tersebut maupun $\mathrm{pH}$ ( keasaman )-nya dapat disimpulkan bahwa air panas di Ciater lebih baik dari pada air panas di taman rekreasi Kanjiza bahkan kandungan besi dari air panas Ciater merupakan kaya Mineral yang terbesar di dunia.Dari hasil kandungan mata air panas alam tersebut dijajagilah kerjasama antara Perusahaan ( PT. Sari Ater Raya ) dengan pihak GENEK ( suatu Badan Hukum / Perusahaan yang mengelola Pusat Rehabilitasi pengguna ari panas di Kanjiza ) untuk transper tekhnologi penyembuhan berbagai macam penyakit melalui terapi dengan menggunakan sumber air panas alami. Kemudian didirikanlah PT. Sari Ater Raya seperti termaksud diatas dengan tujuan mendirikan dan mengusahakan suatu Pusat Rehabilitasi Medik ( Medical Rehabilitasi Centre) untuk mencegah dan menyembuhkan segala macam penyakit serta meningkatkan kesegaran jasmani dengan memanfaatkan sumber air panas yang mengandung berbagai macam mineral. Dengan demikian konsep utama dari perusahaan ini adalah mendirikan Pusat Rehabilitasi Medis bagi mereka yang terkena penyakit tetapi bukan berupa Rumah Sakit dalam hal ini mereka yang sakit total / menginap di rumah sakit. Dengan luas tanah 10 hektar dari 30 hektar yang direncanakan Ciater Spa Resort berdiri sebagai salah satu Perusahaan yang lain daripada yang lain, dimana dengan memanfaatkan kekayaan sumber alam dan kesejukan suasana pegunungan kami mencoba menawarkan kesegaran, kebugaran dan kesehatan bagi para pengunjung. Ciater SPA Resort memiliki visi dan misi sebagai berikut:
1) Visi
- Aman, nyaman, asri
- Memiliki pelayanan yang optimal
- Memanfaatkan Sumber Daya Manusia (SDM) yang unik dan potensial
- Terjaganya kelestarian kerja/lingkungan kerja
- Meningkatkan kesejahteraan stake holder
2) Misi 
- Mengembangkan sektor pariwisata yang berwawasan lingkungan dengan memanfaatkan sumber daya alam (Air Panas Alam)

- Membuka peluang kesempatan kerja kepada masyarakat sekitar untuk pengembangan sektor ekonomi

- Mewujudkan industri pariwisata yang bersaing

\section{Pengaruh Variabel Laten Kualitas Jasa Terhadap Variabel Laten Kepuasan Pelanggan}

Dalam penelitian ini, analisis data yang digunakan adalah analisis Structural Equation Modeling (SEM)-Partial Least Square (PLS) model persamaan struktural atau Structural Equation Modeling (SEM) digunakan untuk menghitung pengaruh yang muncul dari hubungan antara variabel yang diolah berdasarkan dari hasil pengumpulan data responden. Penelitian ini menggunakan data dari responden sebanyak 100 orang yang diolah menggunakan alat analisis model persamaan Struktural - Partial Least Square (SEM-PLS) dengan menggunakan software Smartpls 3.0 lebih bersifat predictive model. Penulis mencoba untuk mengukur hubungan variabel laten kualitas jasa terhadap variabel laten kepuasan pelanggan. Untuk mengukur seberapa besar pengaruh variabel laten kualitas jasa terhadap variabel laten kepuasan pelanggan dengan menggunakan Structural Equation Modeling (SEM) dengan metode Partial Least Square (PLS) berdasarkan analisis model pengukuran (Outer Model) dan model struktural (Inner Model). Analisis model pengukuran dan model struktural ini bertujuan untuk mengetahui hubungan dan tingkat signifikansi antar kedua variabel yang diteliti. Untuk full model sebagai bentuk identifikasi model SEM (Structural Equation Modeling), disajikan dalam gambar dibawah ini :

\section{Gambar 1}

\section{Diagram Path Full Model Analisis SEM (Structural Equation Modeling)}

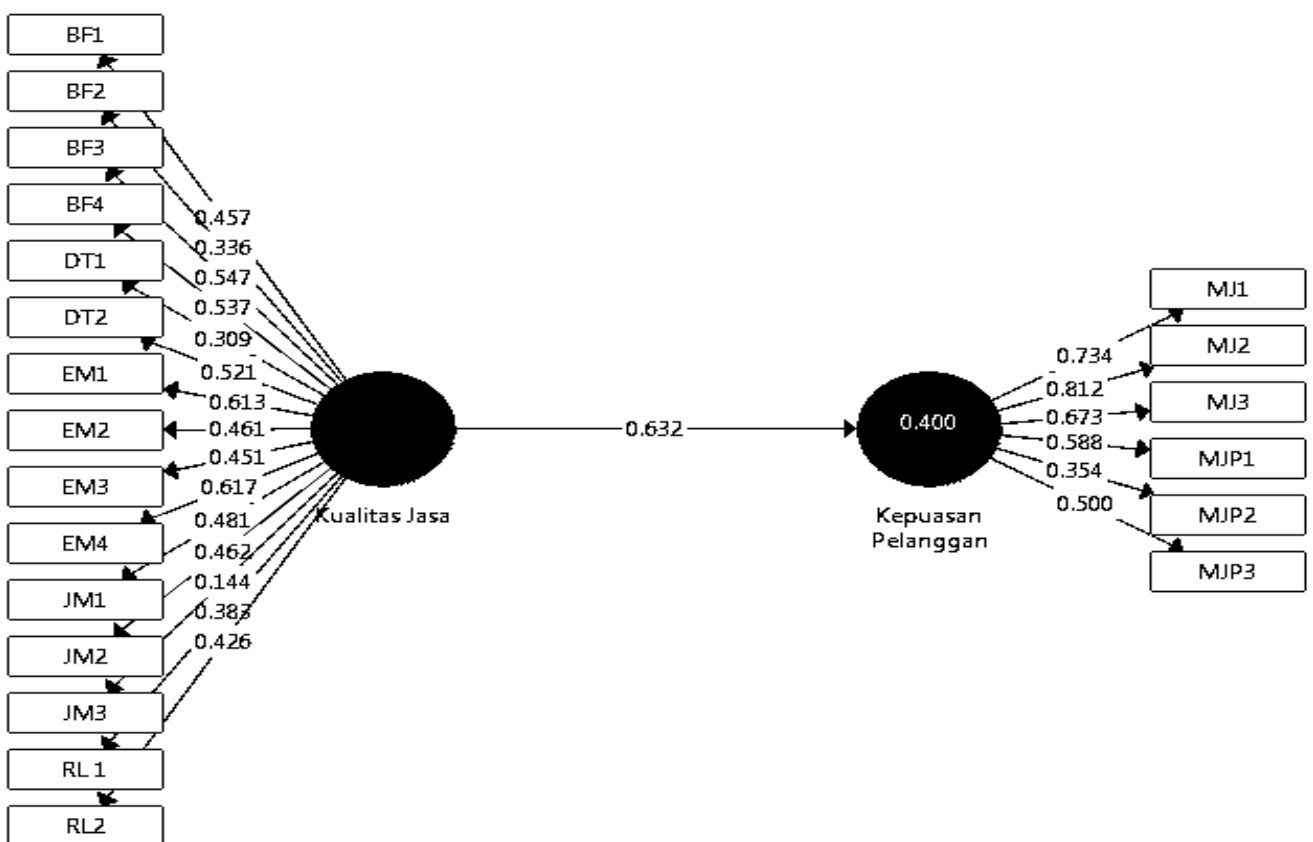

Sumber : Hasil Penelitian 


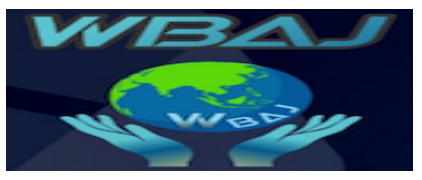

Berdasarkan gambar diatas dapat dilihat cara pengukurannya dengan menggunakan dua puluh satu indikator. Variabel laten kualitas jasa diukur dengan menggunakan lima belas indikator dari lima dimensi, yaitu reliabilitas, daya tanggap, jaminan, empati, dan bukti fisik. Indikatornya terdiri atas ketepatan waktu 1, kecakapan dalam menanggapi keluhan pelanggan serta pemberian pelayanan dengan wajar dan akurat 2, keinginan para staff untuk membantu pelanggan 1, memberikan layanan dengan tanggap 2, pengetahuan 1, kompetensi 2, kesopanan 3 , kemudahan dalam menjalin relasi 1, komunikasi yang baik 2, perhatian pribadi 3, pemahaman atas kebutuhan individual para pelanggan 4, fasilitas fisik 1, perlengkapan 2, pegawai 3, sarana komunikasi 4. Sedangkan variabel laten kepuasan pelanggan diukur dengan menggunakan enam indikator dari dua dimensi, yaitu meminta pelangga menilai produk dan/jasa perusahaan dan meminta pelanggan menilai produk dan/jasa pesaing. Indikatornya terdiri atas kecepatan layanan 1, fasilitas layanan 2, keramahan staff 3, kecepatan layanan 1, fasilitas layanan 2, keramahan staff layanan 3. Untuk memastikan bahwa perhitungan outer loading baik pada model pengukuran maupun model struktural itu signifikan ditempuh langkah "bootsrapping" mendefinisikan beberapa sering model direkalkulasi dengan data sampel yang diciptakan secara random. Cases per sampel, dapat menspesifikan berapa banyak kasus yang dimasukan dalam setiap sampel random, sedangkan prepocesing option dapat memilih dua kemungkinan antara construct level change dan individual sign change. Adapun signifikansi outer loading baik model pengukuran maupun struktural dapat dilihat pada gambar sebagai berikut :

Gambar 2

\section{Diagram Path Model Analisis Metode Bootstrapping}

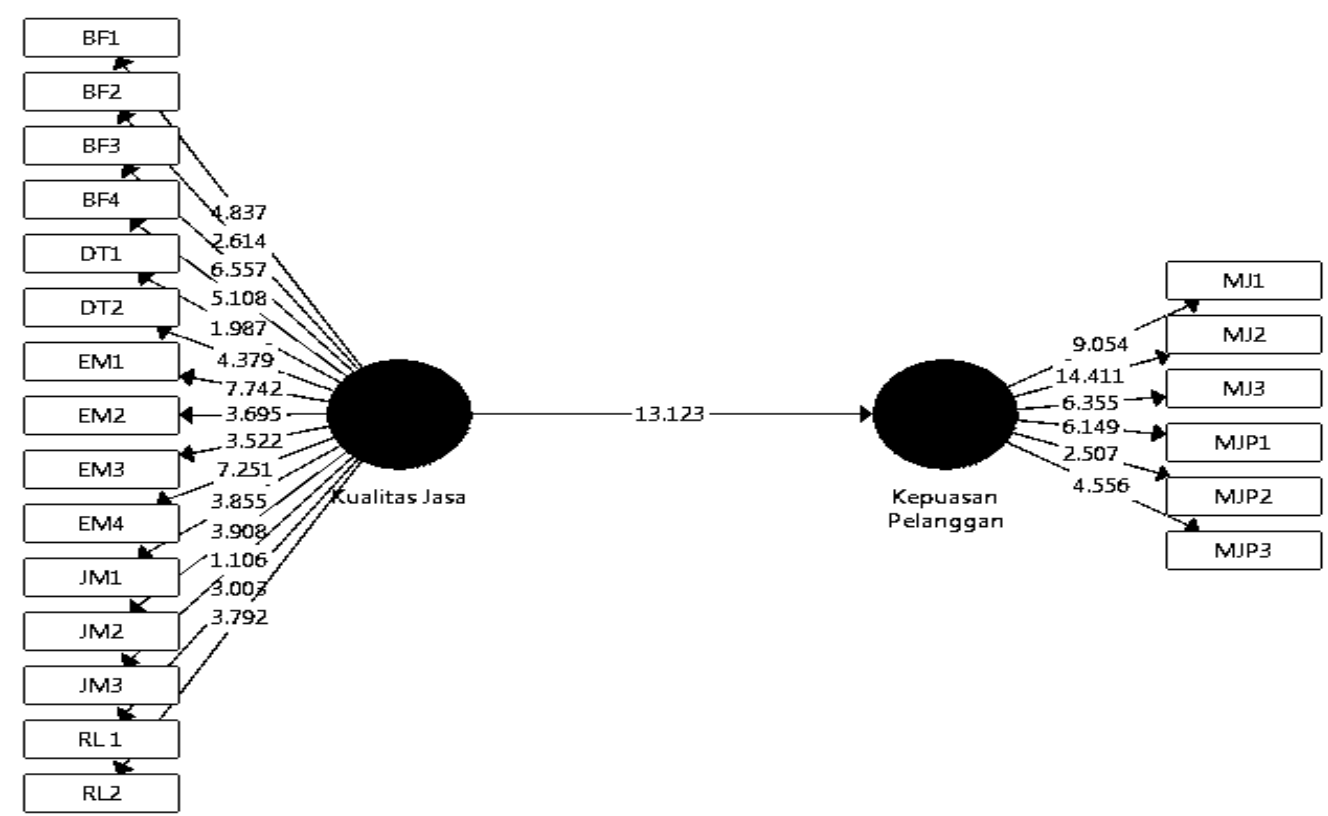

Sumber : Hasil Penelitian

Berdasarkan gambar diatas, terlihat bahwa nilai-nilai loading factor dinyatakan signifikan, karena perolehan nilai hitung t-hitung $>$ t-tabel. Dari kedua variabel 


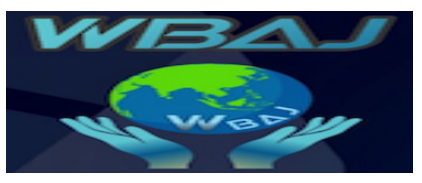

laten kualitas jasa dan variabel laten kepuasan pelanggan sebagaimana disajikan pada gambar 4.16, sebagai berikut :

1) Indikator variabel laten kualitas jasa memiliki factor loading atau koefisien jalur diatas rata-rata 0,521 (lebih besar dari rule of thumbr 0,50), sehingga dapat disimpulkan bahwa indikator tersebut benar-benar dapat mengukur atau merefleksikan variabel laten kualitas jasa. Sementara itu, ada beberapa indikator yang memiliki factor loading atau koefisien jalur dibawah 0,481 (lebih kecil dari rule of thumbr 0,5). Artinya indikator tersebut tidak dapat merefleksikan variabel laten kualitas jasa. Dengan kata lain indikator tersebut memiliki pengaruh sangat kecil dalam menentukan kualitas jasa. Pada indikator variabel laten kualiatas jasa perolehan nilai t-hitung diatas rata-rata 1,987 lebih besar dibanding t-tabel $(1,96)$ sehingga dinyatakan signifikan, namun ada satu indikator tidak signifikan karena perolehan nilai t-hitung 1,106 lebih kecil dibanding t-tabel $(1,96)$.

2) Indikator variabel laten kepuasan pelanggan memiliki factor loading atau koefisien jalur diatas 0,588 (lebih besar dari rule of thumbr 0,50), sehingga dapat disimpulkan bahwa indikator tersebut benar-benar dapat mengukur atau merefleksikan variabel laten kepuasan pelanggan. Sementara itu, ada satu indikator yang memiliki factor loading atau koefisien jalur 0.354 (lebih kecil dari rule of thumbr 0,5), artinya indikator tersebut tidak dapat merefleksikan variabel laten kepuasan pelanggan, dan dinyatakan signifikan karena memiliki nilai thitung dari variabel laten kepuasan pelanggan diatas 2,507 lebih besar dibanding dengan nilai t-tabel $(1,96)$ sehingga dapat disimpulkan indikator ini secara valid mampu mengukur variabel laten kepuasan pelanggan.

Jadi dapat dinyatakan adanya pengaruh dari kualitas jasa terhadap kepuasan pelanggan pada wisata pemandian air panas Ciater SPA Resort dari beberapa indikator memiliki pengaruh yang signifikan artinya kualitas jasa tidak memberikan dampak terhadap kepuasan pelanggan pada wisata pemandian air panas Ciater SPA Resort.

\section{Analisis Model Pengukuran (Outer Model)}

Analisis pengukuran (Outer Model) menjelaskan hubungan antara variabel laten dengan indikatornya. Melalui analisis ini dapat diperoleh informasi apakah indikator valid dan reliabel dalam mengukur variabel laten dapat dilihat indikator mana yang digunakan untuk mengukur variabel laten yang diukur.

Dalam analisis model ini sebuah indikator yang dinyatakan valid dalam mengukur indikatornya jika memiliki factor loading lebih besar dari 0,50 atau secara statistic koefisien reliabilitas konstruk nilainya lebih besar dari 0,70 maka secara umum dapat dinyatakan reliabel. Selain menggunakan ukuran reliabilitas juga dilengkapi dengan ukuran yang dikenal Average Variance Extracted (AVE).

\section{Analisis Model Pengukuran Variabel Laten Kualitas Jasa}

Variabel laten kualitas jasa pada wisata pemandian air panas Ciater SPA Resort diukur dengan menggunakan lima dimensi yaitu reliabilitas (X1), daya tanggap (X2), jaminan (X3), empati (X4), dan bukti fisik (X5), dari lima dimensi tersebut terbagi menjadi 15 indikator pernyataan. Tipe model pengukuran yang digunakan adalah analisis koefisiensi dimana indikator-indikator tersebut 


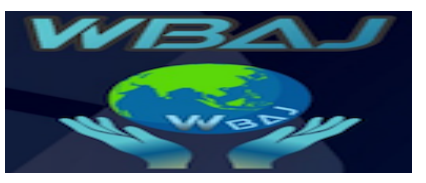

Volume 1 Issue 1, Juni 2019

digunakan untuk merefleksikan atau menjelaskan konstruk variabel laten kualitas jasa. Untuk mengetahui lebih jelas mengenai model pengukuran (Outer Model) yang dilakukan pada variabel laten kualitas jasa dan variabel laten kepuasan pelanggan pada wisata pemandian air panas Ciater SPA Resort dapat dilihat pada gambar berikut :

\section{Gambar 3}

\section{Diagram Path Model Pengukuran Variabel Laten Kualitas Jasa}

Sumber : Hasil Penelitian

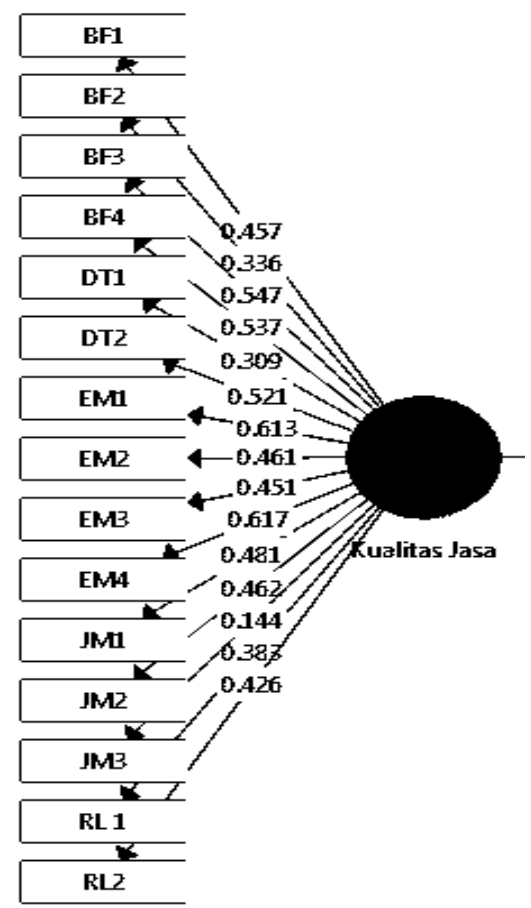

Rangkuman hasil analisis pada Model Pengukuran Variabel Kualitas Jasa ini dapat dilihat pada tabel sebagai berikut :

\section{Tabel 1}

Analisis Model Pengukuran Variabel Laten Kualitas Jasa (n=100)

\begin{tabular}{|c|l|c|c|c|}
\hline \multirow{2}{*}{ No } & Indikator & \multirow{2}{*}{$\begin{array}{c}\text { Cross } \\
\text { Loading }\end{array}$} & \multicolumn{2}{|c|}{ Signifikansi } \\
\cline { 4 - 5 } & & 0,457 & Bootsrapping & Kesimpulan \\
\hline 1 & Bukti fisik & 0,337 & 2,614 & Signifikansi \\
\hline 2 & Bukti fisik & 0,336 & 6,557 & Signifikansi \\
\hline 3 & Bukti fisik & 0,547 & 5,108 & Signifikansi \\
\hline 4 & Bukti fisik & 0,537 & 1,987 & Signifikansi \\
\hline 5 & Daya tanggap & 0,309 & 4,379 & Signifikansi \\
\hline 6 & Daya tanggap & 0,521 & 7,742 & Signifikansi \\
\hline 7 & Empati & 0,613 & 3,695 & Signifikansi \\
\hline 8 & Empati & 0,461 & 3,522 & Signifikansi \\
\hline 9 & Empati & 0,451 & & \\
\hline
\end{tabular}




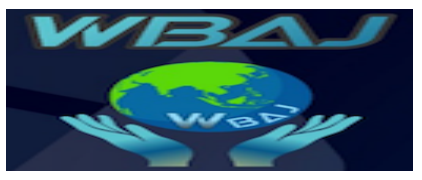

Volume 1 Issue 1, Juni 2019

http://ejournal.unsub.ac.id/index.php/bisnis

\begin{tabular}{|c|l|c|c|c|}
\hline \multirow{2}{*}{ No } & \multirow{2}{*}{ Indikator } & \multirow{2}{*}{$\begin{array}{c}\text { Cross } \\
\text { Loading }\end{array}$} & \multicolumn{2}{|c|}{ Signifikansi } \\
\cline { 4 - 5 } & & 0,617 & Bootsrapping & Kesimpulan \\
\hline 10 & Empati & 0,481 & 3,251 & Signifikansi \\
\hline 11 & Jaminan & 0,462 & 3,855 & Signifikansi \\
\hline 12 & Jaminan & 0,144 & 1,106 & Signifikansi \\
\hline 13 & Jaminan & 0,383 & 3,003 & Signifikansi \\
\hline 14 & Reliabilitas & 0,426 & 3,792 & Signifikansi \\
\hline 15 & Reliabilitas & \multicolumn{3}{|c}{} \\
\hline
\end{tabular}

Sumber : Hasil Penelitian

Berdasarkan tabel diatas, terlihat bahwa nilai factor loading pada koefisien jalur pada variabel laten kualitas jasa dinyatakan empat belas dimensi yang signifikan karena perolehan nilai t-hitung $>\mathrm{t}$-tabel, namun ada satu indikator tidak signifikan karena nilai t-hitung $<$ t-tabel.

Dari lima belas indikator pada variabel laten kualitas jasa sebagaimana disajikan pada tabel 4.10, terlihat bahwa indikator empati yang keempat paling mampu menjelaskan atau merefleksikan kualitas jasa dengan koefisien jalur terbesar yaitu 0,617. Sebaliknya indikator jaminan yang ketiga dinilai paling tidak mampu menjelaskan atau merefleksikan dan memiliki pengaruh paling rendah terhadap variabel laten kualitas jasa yaitu 0,144.

\section{Analisis Model Pengukuran Variabel Laten Kepuasan Pelanggan}

Variabel laten kepuasan pelanggan pada wisata pemandian air panas Ciater SPA Resort diukur dengan menggunakan dua dimensi yaitu meminta pelanggan menilai produk dan/jasa perusahaan (Y1), dan meminta pelanggan menilai produk dan/jasa pesaing (Y2). Dari dua dimensi tersebut terbagi menjadi 6 indikator pernyataan. Tipe model pengukuran yang digunakan adalah analisis koefisien dimana indikator-indikator tersebut digunakan untuk merefleksikan atau menjelaskan konstruk variabel laten kepuasan pelanggan. Untuk mengetahui lebih jelas mengenai model pengukuran (Outer Model) yang dilakukan pada variabel laten kualitas jasa dan variabel laten kepuasan pelanggan pada wisata pemandian air panas Ciater SPA Resort dapat dilihat pada gambar berikut :

\section{Gambar 4}

Model Pengukuran Variabel Laten Kepuasan Pelanggan

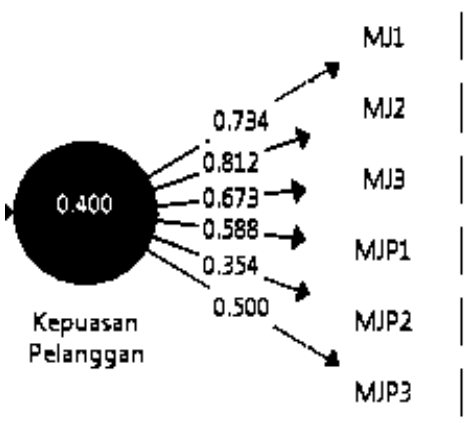

Sumber : Hasil Penelitian 


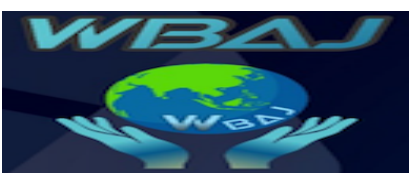

Volume 1 Issue 1, Juni 2019

http://ejournal.unsub.ac.id/index.php/bisnis

Rangkuman hasil analisis pada model pengukuran variabel laten kepuasan pelanggan ini dapat dilihat pada tabel sebagai berikut :

Tabel 2

Analisis Model Pengukuran Variabel Laten Kepuasan Pelanggan (n=100)

\begin{tabular}{|c|l|c|c|c|}
\hline \multirow{2}{*}{ No } & \multicolumn{1}{|c|}{ Indikator } & \multirow{2}{*}{$\begin{array}{c}\text { Cross } \\
\text { Loading }\end{array}$} & \multicolumn{2}{|c|}{ Signifikansi } \\
\cline { 4 - 5 } & & Bootsrapping & Kesimpulan \\
\hline 1 & Menilai jasa pesaing & 0,734 & 9,054 & Signifikansi \\
\hline 2 & Menilai jasa pesaing & 0,812 & 14,411 & Signifikansi \\
\hline 3 & Menilai jasa pesaing & 0,673 & 6,355 & Signifikansi \\
\hline 4 & $\begin{array}{l}\text { Menilai jasa } \\
\text { perusahaan }\end{array}$ & 0,588 & 6,149 & Signifikansi \\
\hline 5 & $\begin{array}{l}\text { Menilai jasa } \\
\text { perusahaan }\end{array}$ & 0,354 & 2,507 & Signifikansi \\
\hline 6 & $\begin{array}{l}\text { Menilai jasa } \\
\text { perusahaan }\end{array}$ & 0,500 & 4,556 & Signifikansi \\
\hline
\end{tabular}

Sumber : Hasil Penelitian

Berdasarkan tabel diatas, terlihat bahwa nilai-nilai factor loading pada koefisien jalur pada variabel laten kepuasan pelanggan dinyatakan semua indikator signifikan, karena perolehan nilai t-hitung $>$ t-tabel. Dari enam indikator pada variabel laten kepuasan pelanggan sebagaimana disajikan pada tabel 4.11, terlihat bahwa indikator menilai jasa pesaing yang kedua paling mampu menjelaskan atau merefleksikan kepuasan pelanggan dengan koefisien jalur terbesar yaitu 0,812. Sebaliknya indikator menilai jasa perusahaan kedua dinilai paling tidak mampu menjelaskan atau merefleksikan dan memiliki pengaruh paling rendah terhadap variabel laten kepuasan pelanggan yaitu 0,354.

\section{Analisis Model Pengukuran Struktural (Inner Model)}

Setelah dilakukan analisis model pengukuran untuk mengukur apakah indikator secara signifikan dalam mengukur variabel latennya, selanjutnya dibawah ini disajikan analisis model struktural. Analisis model struktural adalah analisis pengaruh dari salah satu variabel laten terhadap variabel laten lainnya. Dalam penelitian ini adalah analisis pengaruh kualitas jasa terhadap kepuasan pelanggan pada wisata pemandian air panas Ciater SPA Resort. Analisis model struktural meliputi pengujian berapa besar pengaruh kualitas jasa terhadap kepuasan pelanggan pada wisata pemandian air panas Ciater SPA Resort. Berikut adalah hasil analisis model struktural kualitas jasa terhadap kepuasan pelanggan pada wisata pemandian air panas Ciater SPA Resort : 


\section{Gambar 5 \\ Diagram Path Model Struktural}

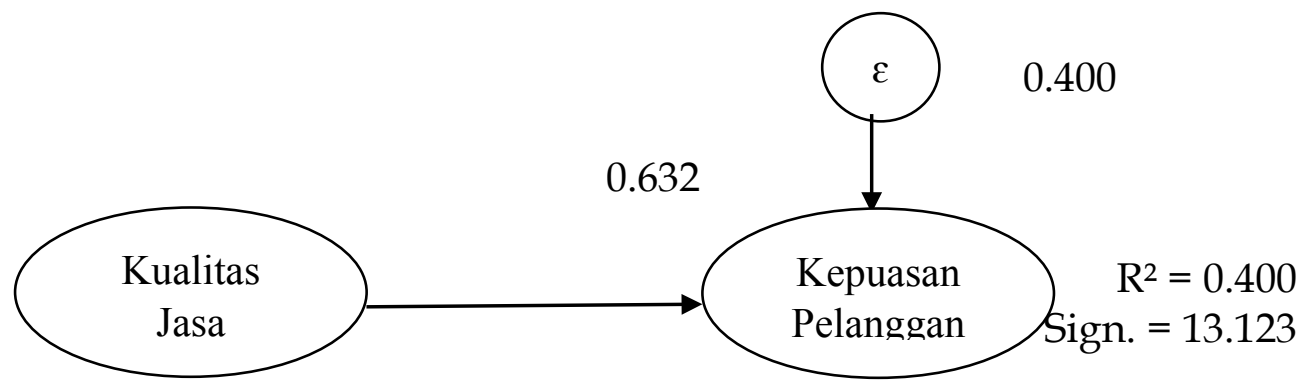

Terlihat dari gambar dan tabel diatas bahwa perhitungan dengan menggunakan software SmartPLS menghasilkan koefisien jalur atau factor loading dari variabel laten kualitas jasa pada wisata pemandian air panas Ciater SPA Resort sebesar 0.632 dengan nilai t-hitung sebesar 13.123. nilai t-hitung ini lebih besar dari 1.96 sebagai rule of thumbs untuk menentukan signifikansi, sehingga hasil evaluasi model struktural ini dinyatakan signifikansi.

Dengan mengkuadratkan koefisien jalur ini diperoleh koefisien determinasi dengan nilai sebesar 0.400 . nilai ini menjelaskan bahwa sebesar $40.0 \%$ keragaman dari variabel laten kepuasan pelanggan pada wisata pemandian air panas Ciater SPA Resort dapat dijelaskan oleh variabel laten kualitas jasa pada wisata pemandian air panas Ciater SPA Resort. Sementara itu sisanya yang dikenal dengan sebutan varians error sebesar 0.400 menjelaskan bahwa sebesar $40.0 \%$ keragaman dari kepuasan pelanggan pada wisata pemandian air panas Ciater SPA Resort dijelaskan oleh variabel lain yang tidak dikaji dalam penelitian ini.

\section{Pengujian Hipotesis}

Setelah dilakukan perhitungan koefisien dalam model penelitian, selanjutnya adalah melakukan hipotesis untuk membuktikan apakah terdapat pengaruh signifikan dari kualitas jasa terhadap kepuasan pelanggan pada wisata pemandian air panas Ciater SPA Resort . Rumusan hipotesis dapat disajikan sebagai berikut :

$\mathrm{H}_{0}=\mathrm{t}_{\text {hitung }}<\mathrm{t}$-tabel $=$ Pengaruh Kualitas Jasa Terhadap Kepuasan Pelanggan wisata pemandian air panas Ciater SPA Resort signifikan.

$\mathrm{H}_{1}=\mathrm{t}_{\text {hitung }}>\mathrm{t}$-tabel $=$ Pengaruh Kualitas Jasa Terhadap Kepuasan Pelanggan wisata pemandian air panas Ciater SPA Resort tidak signifikan.

Berdasarkan hasil penelitian hipotesis tidak terdapat pengaruh kualitas jasa terhadap kepuasan pelanggan pada wisata pemandian air panas Ciater SPA Resort sebesar 13.123, lebih besar dibanding dengan nilai t-tabel $(1,96)$ sehingga dapat diputuskan bahwa hipotesis nol diterima dan hipotesis satu ditolak atau dengan kata lain terdapat pengaruh signifikan dari kualitas jasa terhadap kepuasan pelanggan pada wisata pemandian air panas Ciater SPA Resort. Kualitas jasa memberikan kontribusi terhadap kepuasan pelanggan secara signifikan dengan besar pengaruh 13.123. Sehingga dapat disimpulkan bahwa pengaruh kualitas jasa dapat merefleksikan atau menggambarkan kepuasan pelanggan.

Hasil analisis deskriptif menunjukan bahwa secara umum kualitas jasa terhadap kepuasan pelanggan pada wisata pemandian air panas Ciater SPA Resort dinilai tinggi. Hal ini dapat dilihat dari hasil skor indeks rata-rata pertimbangan 
yang diperoleh oleh variabel laten kualitas jasa 3.45, sedangkan untuk variabel laten kepuasan pelanggan mencapai 2.49. Temuan analisis deskriptif kualitas jasa terhadap kepuasan pelanggan pada wisata pemandian air panas Ciater SPA Resort memberikan implikasi bahwa apabila kualitas jasa tidak diberikan secara layak dan baik maka pelanggan tidak akan puasa dengan hasil yang didapatkannya. Sebaliknya apabila kualitas jasa secara layak dan baik maka pelanggan akan merasa puas atas kontribusi yang didapatkannya.

Dilihat dari variabel laten kualitas jasa menunjukan skor tinggi sebesar 3.45, dengan demikian, data tersebut memberikan pemahaman bahwa wisata pemandian air panas Ciater SPA Resort harus memberikan kualitas jasa yang baik sesuai dengan kemampuan perusahaan dan memenuhi apa yang dibutuhkan oleh pelanggan wisata pemandian air panas Ciater SPA Resort. Pada variabel laten kepuasan pelanggan menunjukan skor yang rendah sebesar 2.49, hal ini menandakan bahwa kepuasan pelanggan pada wisata pemandian air panas Ciater SPA Resort kurang baik karena kepuasan itu sendiri sangat dipentingkan demi kenyamanan pelanggan dan sangat berperan penting bagi setiap perusahaan. Kepuasan pelanggan akan semakin meningkat apabila adanya pemberian kualitas jasa yang baik yang diberikan wisata pemandian air panas Ciater SPA Resort . Dengan diberikannya kualitas jasa yang baik maka pelanggan akan merasakan senang dan puas berkunjung ke wisata pemandian air panas Ciater SPA Resort.

Pada uraian diatas terlihat bahwa kualitas jasa memiliki relevansi yang kuat dengan kepuasan pelanggan baik secara konseptual, maupun secara empirik. Hal ini dikarenakan kualitas jasa menjadi acuan dan tolak ukur bagi kepuasan pelanggan pada wisata pemandian air panas Ciater SPA Resort. Dengan demikian kualitas jasa yang baik akan berpengaruh terhadap kepuasan pelanggan pada wisata pemandian air panas Ciater SPA Resort.

\section{Kesimpulan}

Berdasarkan uraian dan penelitian yang telah dilakukan, maka tahap terakhir dari penulisan skripsi ini penulis menarik beberapa kesimpulan sesuai dengan tujuan dari penulisan skripsi ini. Berdasarkan hasil analisis data dan informasi yang diperoleh sebagaimana dijelaskan pada bab sebelumnya, maka dapat ditarik kesimpulan sebagai berikut :

1) Tingkat kualitas jasa pada wisata pemandian air panas Ciater SPA Resort dinilai tinggi.

2) Tingkat kepuasan pelanggan pada wisata pemandian air panas Ciater SPA Resort dinilai rendah.

3) Berdasarkan hasil penelitian diperoleh hasil analisis regresi dengan menggunakan software SmartPLS menghasilkan koefisien jalur atau factor loading dari variabel kualitas jasa terhadap kepuasan pelanggan pada wisata pemandian air panas Ciater SPA Resort sebesar 0,632. Dengan mengkuadratkan koefisien jalur ini diperoleh koefisien determinasi dengan nilai sebesar 0,400 nilai ini menjelaskan bahwa sebesar $40.0 \%$ keragaman dari variabel laten kepuasan pelanggan pada wisata pemandian air panas Ciater SPA Resort dapat dijelaskan oleh variabel laten kualitas jasa pada wisata pemandian air panas Ciater SPA Resort. Sementara itu sisanya yang dikenal dengan sebutan varians error sebesar 0.400 menjelaskan bahwa sebesar $40.0 \%$ keragaman dari kepuasan 


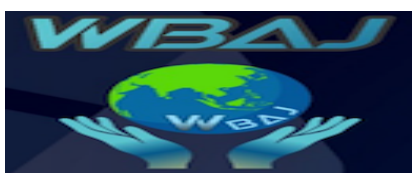

pelanggan pada wisata pemandian air panas Ciater SPA Resort dijelaskan oleh variabel lain yang tidak dikaji dalam penelitian ini.

\section{Referensi}

Ahmad Safrizal Yafie, Suharyono, Yusri Abdillah, (2016), Pengaruh Kualitas Produk atau Kualitas Jasa terhadap Kepuasan Pelanggan, Jurnal Administrasi Bisnis Vol. 35 No. 2

Fandy Tjiptono, (2014), Pemasaran Jasa, Yogyakarta : Penerbit ANDI

Fandy Tjiptono \& Gregorius Chandra, (2011), Service, Quality \& Statisfaction, edisi 3. Yogyakarta: Penerbit ANDI

Ghazali Imam 2014. Structural Equation Modeling Metode Alternatif dengan Partial Least Squarea (PLS). Universitas Diponogoro:Semarang

Malayu S.P Hasibuan, (2011), Manajemen: Dasar, Pengertian, dan Masalah, Bumi Aksara, Jakarta

Philip Kotler dan Kevin Lane Keller, (2009), Manajemen Pemasaran jilid I, edisi ketiga belas, Jakarta : Erlangga

Sugiyono, (2014), Metode Penelitian Bisnis, Alfabeta, Bandung

Sugiyono, (2012), Statistik Untuk Metode Penelitian Bisnis, Edisi 10. CV. Alfabeta, Bandung

Sugiyono. 2011. Metode Penelitian Kuantitatif, Kualitatif dan RED. Bandung: Afabeta

Supranto. 2006. Pengukuran Tingkat Kepuasan Pelanggan. Jakarta: Rineka. Cipta. 